\title{
ОСОБЛИВОСТІ НУТРИЦІЙНОГО СТАТУСУ У ХВОРИХ ІЗ ХРОНІЧНОЮ ХВОРОБОЮ НИРОК: ЗВ'ЯЗОК ІЗ ІНТЕРЛЕЙКІНОМ 6 ТА ФАКТОРОМ РОСТУ ФІБРОБЛАСТІВ 23
}

\author{
๑М. І. Чайковська \\ ДВНЗ «Тернопільський державний медичний університет імені І. Я. Горбачевського МОз України»
}

РЕЗЮМЕ. Зниження нутриційного статусу пацієнтів із хронічною хворобою нирок (XXH) пов'язане зі зростанням ризику захворюваності та смертності. У дослідженні показано зв'язок маркерів нутриційного статусу, а саме товщини шкірно-жирової складки, із маркером запалення інтерлейкіном 6 та фосфатуричним гормоном фактором росту фібробластів 23, кількість якого зростає при XXН, що асоціюється з підвищенням серцево-судинної смертності.

Мета - вивчити особливості нутриційного статусу хворих із ХХН та дослідити зв'язки ФРФ-23 та ІЛ-6 із показниками нутриційного статусу при XXH.

Матеріал і методи.У дослідженні брали участь 106 осі6, 47 жінок (44 \%) та 59 чоловіків (56\%), віком $(49,6 \pm 13,9)$ років, із ХХН. Дослідження включало визначення рівнів альбуміну, ІЛ-6, IMT, товщини ШЖС. С-кінцевий фрагмент ФРФ-23 визначали за допомогою набору реактивів для імуноферментного аналізу «Biomedica» на апараті STAT FAX 303 Plus.

Результати. Рівень альбуміну сироватки крові прогресивно знижувався, досягаючи мінімальних значень при термінальній стадії ниркової недостатності $(p<0,001)$. Серед пацієнтів із XXH V недостатність харчування спостерігали у 31 \% хворих, з них у 10 \% виявлено середній ступінь недостатності харчування та у 5 \% - тяжку недостатність харчування. Товщина ШЖС зменшувалася паралельно з падінням ШКФ, набуваючи статистичної значущості при XXH III $(p<0,01)$ та досягаючи найнижчих значень при XXH V. Виявлено достовірний зворотний зв'язок між товщиною ШЖС та концентрацією ФРФ-23 ( $r=-0,23 ; p<0,05)$, між товщиною ШЖС та концентрацією ІЛ-6 ( $r=-0,23 ; p<0,05)$.

Висновки. Товщина ШЖС зменшується із падінням ШКФ та має зворотний зв'язок із рівнем ІЛ-6, що свідчить про нутритивні властивості підшкірних жирових депо і відсутність у них прозапального впливу у пацієнтів із XXH.

КЛЮчОВІ СЛОВА: хронічна хвороба нирок; нутриційний статус; білково-енергетична недостатність; хронічне запалення; фактор росту фібробластів 23; інтерлейкін 6.

Вступ. Хронічна хвороба нирок (ХХH) набирає щораз більшої поширеності в Україні та світі. Близько $10 \%$ населення планети має ураження нирок.

Білково-енергетична недостатність (БЕН) у пацієнтів з XXН пов'язана з несприятливими клінічними наслідками, особливо в осіб, які отримують підтримувальну діалізну терапію. Діалізні техніки та догляд за пацієнтами неухильно розвиваються, тоді як поширеність зниження нутриційного статусу залишається на тому ж рівні і складає, за даними епідеміологічних досліджень, від 30 до $70 \%$ [1].

БEН $€$ станом, при якому знижені запаси білка та енергії (тобто жирів) в організмі. Нутриційний статус та метаболізм хворих із XXН перебуває під впливом багатьох чинників, серед яких підвищення катаболізму білка внаслідок уремічної інтоксикації, обмеження надходження білка (внаслідок анорексії, нудоти і блювання, які розвиваються при уреміі), недостатність анаболічних гормонів (інсуліноподібний фактор росту 1, соматотропін) [2-4], підвищення рівня катаболічних гормонів, таких як глюкагон [5], паратгормон [6], інсулінорезистентність [7], дисбаланс лептину, греліну, YY пептиду та обестатину, що пояснює анорексію у цієї категорії пацієнтів [8 - 10], втрата метаболічної активності нирок та розвиток метаболічного ацидозу, дієтичні обмеження.
Значно поширене при XXH також хронічне запалення, що пов'язане $з$ розвитком серцево-судинних ускладень, БЕН та смертністю $[11,12]$. Встановлено, що ІЛ-6 $€$ кращим предиктором загальної та серцево-судинної смертності, ніж СРБ та інші цитокіни, такі як ФНП-а, ІЛ-1 $\beta$ та ІЛ-18 $[13,14]$.

Фактор росту фібробастів 23 (ФРФ-23) $\epsilon$ гормоном кісткового походження, що необхідний для підтримки нормального рівня фосфату та гомеостазу вітаміну $D_{3}$ [15]. Рівень ФРФ-23 при XXH прогресивно зростає, а висока його концентрація міцно зв'язана з підвищеним ризиком прогресування XXH, розвитку серцево-судинних ускладнень та смертності [16].

Незважаючи на те, що численні епідеміологічні дані свідчать про те, що покращення біомаркерів нутриційного статусу пов'язане з покращенням виживання, відсутні великі клінічні дослідження зв'язків маркерів запалення та ФРФ-23 із показниками нутриційного статусу хворих із ХХН.

Мета - вивчити особливості нутриційного статусу хворих із XXН шляхом оцінки сироваткової концентрації альбуміну, визначення IMT та товщини шкірно-жирової складки (ШЖС) та дослідити зв'язки сироваткової концентрації с-кінцевого фрагменту ФРФ-23 та ІЛ-6 із показниками нутриційного статусу при XXН.

Матеріал і методи досліджень. Нами обстежено 106 осіб, 47 жінок (44 \%) та 59 чоловіків 
Огляди літератури, оригінальні дослідження, погляд на проблему, ювілеї

(56\%), віком $(49,6 \pm 13,9)$ років, із XXН, які перебували на стаціонарному обстеженні та лікуванні в нефрологічному відділенні КЗ ТОР «Тернопільська університетська лікарня». Обстежених хворих було поділено на 5 груп: першу групу склали пацієнти із ШКФ $\geq 90$ мл/(Хв·1,73м²) (XXH I, $n=9)$, другу групу пацієнти із ШКФ 60-89 мл/(ХВ·1,73м²) (XXH II, $\mathrm{n}=6)$,

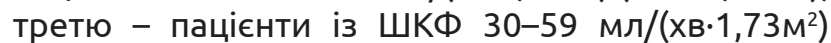
(XXH III, n=23), четверту - пацієнти із ШКФ 15$29 \mathrm{мл/(Хв \cdot 1,73м^{2 } ) ( X X H ~ I V , ~ n = 2 9 ) , ~ п ' я т у ~ - ~ х в о р і ~ і з ~}$ ШКФ < 15 мл/(Хв·1,73м²) (XXH V, n=39). Визначення рівня с-кінцевого фрагменту ФРФ-23 проводили у пацієнтів із XXH I-V стадій та у контрольній групі, до якої увійшли 9 здорових осіб віком $(41,9 \pm 13,6)$ років.

ШКФ розраховували за формулою CKD EPI (KDIGO 2012). IMT розраховували за формулою Кетле: IMT = маса тіла (кг)/(зріст (м))2.

Лабораторні дослідження включали визначення сироваткового рівня альбуміну за допомогою біохімічного аналізатора Cobas Integra 400 Plus. С-кінцевий фрагмент ФРФ-23 визначали за допомогою набору реактивів для імуноферментного аналізу «Biomedica» (Австрія), ІЛ-6 визначали за допомогою набору реактивів для імуноферментного аналізу «Вектор Бест» на апараті STAT FAX 303 Plus.
Антропометричні дослідження включали визначення товщини ШЖС над тріцепсом, над лопаткою та на животі на рівні пупка із зазначенням їх суми (ШЖС-с), а також розрахунок IMT за формулою Кетле: IMT = маса тіла (кг)/(зріст (м))2.

Статистичну обробку отриманих даних виконували за допомогою програм Microsoft Excell 2010, Statistica 10.0. Дані з нормальним розподілом представлені як середнє士стандартне відхилення. Дані, що не підпорядковувались нормальному закону розподілу, представлені як медіана та інтерквартильний розмах (IKP). Нормальність розподілу перевіряли за критеріями Колмогорова-Смирнова та Шапіро-Уїлка. Сатистичну достовірність відмінностей між кількісними показниками оцінювали за показником Манна-Уїтні (U). Зв'язок між показниками визначали за коефіцієнтом рангової кореляції Спірмена (R).

Результати й обговорення. При обстеженні пацієнтів із XXH I-V стадій (табл. 1) виявлено тенденцію до зростання IMT на 2 стадії $\mathrm{XXH}$, порівняно з XXH I, із наступним прогресивним його зниженням до XXH IV $(p<0,05$, порівняно із XXH II), проте на 5 стадії IMT несуттєво зростав.

Таблиця 1. Лабораторні характеристики обстежених пацієнтів

\begin{tabular}{|c|c|c|c|c|c|}
\hline \multirow[b]{2}{*}{ Показник } & \multicolumn{5}{|c|}{ Група пацієнтів } \\
\hline & $\begin{array}{l}X X H I, \\
N=9\end{array}$ & $\begin{array}{l}\text { XXH II, } \\
N=6\end{array}$ & $\begin{array}{l}\mathrm{XXH} \text { III, } \\
\mathrm{N}=23\end{array}$ & $\begin{array}{l}\text { XXH IV, } \\
\mathrm{N}=29\end{array}$ & $\begin{array}{l}X X H V, \\
N=39\end{array}$ \\
\hline ШКФ, мл/(хв·1,73м²) & $\begin{array}{c}114,6 \\
(107,6-118,0) \\
\end{array}$ & $\begin{array}{c}73,0 \\
(68,9-77,6)^{* *}\end{array}$ & $\begin{array}{c}42,5 \\
(32,3-47,5)^{* * *}\end{array}$ & $\begin{array}{c}23,4 \\
(20,5-26,2)^{* * *}\end{array}$ & $6,1(4,6-8,6)^{* * *}$ \\
\hline IMT & $26,7(25,0-29,4)$ & $29,8(29,3-32,2)$ & $26,7(24,8-30,0)$ & $25,0(24,4-28,4)$ & $27,2(24,9-30,1)$ \\
\hline Альбумін, г/л & $41,13 \pm 3,53$ & $37,22 \pm 3,5$ & $38,76 \pm 3,27$ & $38,53 \pm 3,46^{*}$ & $35,57 \pm 4,03 * * *$ \\
\hline ШЖС-с, мМ & $66,56 \pm 9,74$ & $55,5 \pm 6,16$ & $57 \pm 8,25 * *$ & $55,45 \pm 7,69 * *$ & $54,31 \pm 7,98 * *$ \\
\hline ІЛ-6, пг/мл & $7,25 \pm 2,14$ & $6,54 \pm 1,38$ & $29,31 \pm 5,49 * * *$ & $46,27 \pm 10,58 * * *$ & $82,46 \pm 7,62 * * *$ \\
\hline ФРФ-23, пмоль/л & $0,75(0,71-0,82)$ & $0,81(0,76-0,84)^{*}$ & $\begin{array}{c}1,76 \\
(1,69-1,81)^{* * *}\end{array}$ & $\begin{array}{c}1,83 \\
(1,72-2,11)^{* * *}\end{array}$ & $\begin{array}{c}18,25 \\
(14,15-20,30)^{* * *}\end{array}$ \\
\hline
\end{tabular}

Примітка: порівняно з групою хворих із XXH I: * - p $<0,05 ;$ ** - p $<0,01$; *** - p $<0,001$.

Рівень альбуміну сироватки крові мав тенденцію до зниження вже при XXH II, i, після деякого підвищення при 3 стадії XXН, продовжував падати, досягаючи мінімальних значень при термінальній стадії ниркової недостатності $(p<0,001)$. Серед пацієнтів із XXH V недостатність харчування спостерігалась у 31 \% хворих, з них у $10 \%$ виявлено середній ступінь недостатності харчування та у $5 \%$ - важку недостатність харчування.

Товщина ШЖС зменшувалась паралельно з падінням ШКФ, набуваючи статистичної значущості при XXH III $(p<0,01)$ та досягаючи найнижчих значень при XXH V.

Виявлено достовірний зворотний зв'язок між товщиною ШЖС та концентрацією ФРФ-23 ( $r=-0,23$; $\mathrm{p}<0,05)$, між товщиною ШЖС та концентрацією
ІЛ-6 ( $r=-0,23 ; p<0,05)$, що свідчить про нутрітивні властивості підшкірних жирових депо і відсутність у них прозапального впливу у пацієнтів із XXH.

Кореляція ІМТ із ФРФ-23 та ІЛ-6 виявилась відсутньою, що опосередковано свідчить про нездатність IMT самостійно відображати стан жирового депо організму.

Один з основних побічних ефектів XXН - поступове скорочення запасів білка та енергії - досягає максимуму при діалізній терапії та виявляється задовго до розвитку термінальної ниркової недостатності, що корелює з даними досліджень [17].

Складність такої ситуації потребує комбінації терапевтичних заходів, щоб запобігти або зменшити дефіцит білка та енергії. До них належать оптимізація споживання дієтичних поживних ре- 
Огляди літератури, оригінальні дослідження, погляд на проблему, ювілеї

човин, належне лікування метаболічних порушень, таких як метаболічний ацидоз, системне запалення та гормональний дисбаланс.

Висновки. Розвиток ниркової недостатності супроводжується прогресивним виснаженням білково-енергетичних запасів організму, що ко- релює з посиленням запалення та підвищенням продукції ФРФ-23. Товщина ШЖС зменшується із падінням ШКФ та має зворотний зв'язок із рівнем ІЛ-6, що свідчить про нутрітивні властивості підшкірних жирових депо і відсутність у них прозапального впливу у пацієнтів із XXH.

\section{ЛІТЕРАТУРА}

1. Foley R. N. Hypoalbuminemia, cardiac morbidity, and mortality in end-stage renal disease / R. N. Foley, P. S. Parfrey, J. D. Harnett // J. Am. Soc. Nephrol. - 2006. - No. 7. P. 728-736.

2. Mehls O. Improvement of growth and food utilization by human recombinant growth hormone in uremia / O. Mehls, E. Ritz, E. B. Hunziker // Kidney Int. - 1988. No. 33. - P. 45-52.

3. Hazel S. J. Enhanced body growth in uremic rats treated with IGF-I and growth hormone in combination / S. J. Hazel, C. M. Gillespie, R. J. Moore // Kidney Int. - 1994. No. 46. - P. 58-68.

4. Guebre-Egziabher F. Short-term administration of a combination of recombinant growth hormone and insulinlike growth factor-I induces anabolism in maintenance hemodialysis / F. Guebre-Egziabher, L. Juillard, Y. Boirie // J. Clin. Endocrinol. Metab. - 2009. - No. 94. - P. 2299-2305.

5. Sherwin R. S. Influence of uremia and hemodialysis on the turnover and metabolic effects of glucagon / R. S. Sherwin, C. Bastl, F. O. Finkelstein // J. Clin. Invest. - 1976. No. 57. - P. 722-731.

6. Kopple J. D. Does parathyroid hormone cause protein wasting? / J. D. Kopple, B. Cianciaruso, S. G. Massry // Contrib. Nephrol. - 1980. - No. 20. - P. 138-148.

7. Mak R. H. Insulin resistance but IGF-I sensitivity in chronic renal failure / R. H. Mak // Am. J. Physiol. - 1996. No. 271. - P. F114-F119.

8. Korner J. To eat or not to eat-how the gut talks to the brain / J. Korner, R. L. Leibel // N. Engl. J. Med. - 2003. No. 349. - P. 926-928.

9. Mafra D. Are ghrelin and leptin involved in food intake and body mass index in maintenance hemodialysis? / D. Mafra, A. Jolivot, P. Chauveau // J. Ren. Nutr. - 2010. No. 20. - P. 151-157.

\section{REFERENCES}

1. Foley, R. N., Parfrey, P.S., \& Harnett, J.D. (2006). Hypoalbuminemia, cardiac morbidity, and mortality in end-stage renal disease. J. Am. Soc. Nephrol, 7, 728-736.

2. Mehls, O., Ritz, E., \& Hunziker, E.B. (1988). Improvement of growth and food utilization by human recombinant growth hormone in uremia. Kidney Int., 33, 45-52.

3. Hazel, S.J., Gillespie, C.M., \& Moore, R.J. (1994). Enhanced body growth in uremic rats treated with IGF-I and growth hormone in combination. Kidney Int., 46, 58-68.

4. Guebre-Egziabher, F., Juillard, L., \& Boirie, Y. (2009). Short-term administration of a combination of recombinant growth hormone and insulin-like growth factor-I induces
10. Mak R. H. Adipokines and gut hormones in endstage renal disease / R. H. Mak, W. Cheung // Perit. Dial Int. 2007. - No. 27 (Suppl. 2). - P. S298-S302.

11. Stenvinkel P. Strong association between malnutrition, inflammation, and atherosclerosis in chronic renal failure / P. Stenvinkel, O. Heimburger, F. Paultre // Kidney Int. - 1999. - No. 55. - P. 1899-1911.

12. Inflammation enhances cardiovascular risk and mortality in hemodialysis patients / J. Zimmermann, S. Herrlinger, A. Pruy [et al.] // Kidney Int. - 1999. - No. 55. P. 648-658.

13. Honda H. Serum albumin, C-reactive protein, interleukin 6 , and fetuin a as predictors of malnutrition, сагdiovascular disease, and mortality in patients with ESRD / H. Honda, A. R. Qureshi, O. Heimburger // Am. J. Kidney Dis. - 2006. - No. 47. - P. 139-148.

14. Tripepi G. Inflammation markers, adhesion molecules, and allcause and cardiovascular mortality in patients with ESRD: searching for the best risk marker by multivariate modeling / G. Tripepi, F. Mallamaci, C. Zoccali // J. Am. Soc. Nephrol. - 2005. - No. 16. - P. S83-S88.

15. Martin A. Regulation and function of the FGF23/ klotho endocrine pathways / A. Martin, V. David, L. D. Quarles // Physiol. Rev. - 2012. - No. 92. - P. 131-155.

16. Gutierrez O. M. Fibroblast growth factor 23 and mortality among patients undergoing hemodialysis / O. M. Gutierrez, M. Mannstadt, T. Isakova // N. Engl. J. Med. - 2008. No. 359. - P. 584-592.

17. Kopple J. D. Relationship between nutritional status and the glomerular filtration rate: results from the MDRD study / J. D. Kopple, T. Greene, W. C. Chumlea // Kidney Int. - 2000. - No. 57. - P. 1688-1703.

anabolism in maintenance hemodialysis. J. Clin. Endocrinol. Metab., 94, 2299-2305.

5. Sherwin, R.S., Bastl, C., \& Finkelstein, F.O. (1976). Influence of uremia and hemodialysis on the turnover and metabolic effects of glucagon. J. Clin. Invest., 57, 722-731.

6. Kopple, J.D, Cianciaruso, B., \& Massry, S.G. (1980). Does parathyroid hormone cause protein wasting? Contrib. Nephrol., 20, 138-148.

7. Mak, R.H. (1996). Insulin resistance but IGF-I sensitivity in chronic renal failure. Am. J. Physiol., 271, F114-F119.

8. Korner, J., \& Leibel, R.L. (2003). To eat or not to eathow the gut talks to the brain. N. Engl. J. Med., 349, 926-928. 
Огляди літератури, оригінальні дослідження, погляд на проблему, ювілеї

9. Mafra, D., Jolivot, A., \& Chauveau, P. (2010). Are ghrelin and leptin involved in food intake and body mass index in maintenance hemodialysis? J. Ren. Nutr., 20, 151157.

10. Mak, R.H., \& Cheung, W. (2007). Adipokines and gut hormones in end-stage renal disease. Perit. Dial. Int., 27 (Suppl 2), S298-S302.

11. Stenvinkel, P., Heimburger, O., \& Paultre, F. (1999). Strong association between malnutrition, inflammation, and atherosclerosis in chronic renal failure. Kidney Int., 55, 1899-1911.

12. Zimmermann, J., Herrlinger, S., Pruy, A., Metzger, T., \& Wanner, C. (1999). Inflammation enhances cardiovascular risk and mortality in hemodialysis patients. Kidney Int., 55, 648-658.

13. Honda, H., Qureshi, A.R., \& Heimburger, O. (2006). Serum albumin, C-reactive protein, interleukin 6, and fetuin a as predictors of malnutrition, cardiovascular disease, and mortality in patients with ESRD. Am. J. Kidney Dis., 47, 139-148.

14. Tripepi, G., Mallamaci, F., \& Zoccali, C. (2005). Inflammation markers, adhesion molecules, and allcause and cardiovascular mortality in patients with ESRD: searching for the best risk marker by multivariate modeling. J. Am. Soc. Nephrol., 16, S83-S88.

15. Martin, A., David, V., \& Quarles, L.D. (2012). Regulation and function of the FGF23/klotho endocrine pathways. Physiol. Rev., 92, 131-155.

16. Gutierrez, O.M., Mannstadt, M., \& Isakova, T. (2008). Fibroblast growth factor 23 and mortality among patients undergoing hemodialysis. N. Engl. J. Med., 359, 584-592.

17. Kopple, J.D., Greene, T., \& Chumlea, W.C. (2000). Relationship between nutritional status and the glomerular filtration rate: results from the MDRD study. Kidney Int., 57, 1688-1703.

\title{
ОСОБЕННОСТИ НУТРИЦИОННОГО СТАТУСА БОЛЬНЫХ С ХРОНИЧЕСКОЙ БОЛЕЗНЬЮ ПОЧЕК: СВЯЗЬ С ИНТЕРЛЕЙКИНОМ 6 И ФАКТОРОМ РОСТА ФИБРОБЛАСТОВ 23
}

๑М. И. Чайковская

\author{
ГВУз “Тернопольский государственный медицинский университет имени И. Я. Горбачевского \\ МЗ Украины"
}

PЕЗЮМЕ. Снижение нутриционного статуса пациентов с хронической болезнью почек (ХБП) связано с ростом риска заболеваемости и смертности. В исследовании показана связь маркеров нутриционного статуса, а именно толщины кожно-жировой складки, с маркером воспаления интерлейкином 6 и фосфатурическим гормоном фактором роста фибробластов 23, количество которого возрастает при ХБП, что ассоциируется с повышением сердечно-сосудистой смертности.

Цель - изучить особенности нутриционного статуса больных с ХБП и исследовать связи ФРФ-23 и ИЛ-6 с показателями нутриционного статуса при ХБП.

Материал и методы. В исследовании принимали участие 106 человек, 47 женщин (44 \%) и 59 мужчин (56 \%) в возрасте $(49,6 \pm 13,9)$ лет с ХБП. Исследования включали определение уровней альбумина, ИЛ-6, ИМТ, толщины КЖС над трицепсом, над лопаткой и на животе. С-конечный фрагмент ФРФ-23 определяли с помощью набора реактивов для иммуноферментного анализа «Biomedica» на аппарате STAT FAX 303 Plus.

Результаты. Уровень альбумина сыворотки крови прогрессивно снижался, достигая минимальных значений на терминальной стадии почечной недостаточности $(\mathrm{p}<0,001)$. Среди пациентов с ХБП $V$ недостаточность питания наблюдалась у 31 \% больных, из них у 10 \% выявлена средняя степень недостаточности питания и у 5 \% тяжелая недостаточность питания. Толщина КЖС уменьшалась параллельно с падением СКФ, приобретая статистическую значимость при ХБП III $(p<0,01)$ и достигая самых низких значений при ХБП V. Выявлена достоверная обратная связь между толщиной КЖС и концентрацией ФРФ-23 ( $~=-0,23$; $<<0,05)$, между толщиной КЖС и концентрацией ИЛ-6 ( $r=-0,23 ; p<0,05)$.

Выводы. Толщина КЖС уменьшается с падением СКФ и обладает обратной связью с уровнем ИЛ-6, что свидетельствует о нутритивных свойствах подкожных жировых депо и отсутствии у них провоспалительных влияний У пациентов С ХБП.

КЛЮчЕВЫЕ СЛОВА: хроническая болезнь почек; нутриционный статус; белково-энергетическая недостаточность; хроническое воспаление; фактор роста фибробластов 23; интерлейкин 6.

\section{FEATURES OF NUTRITIONAL STATUS IN PATIENTS WITH CHRONIC KIDNEY DISEASE: RELATION WITH INTERLEUKIN 6 AND FIBROBLAST GROWTH FACTOR 23}

\section{Horbachevsky Ternopil State Medical University}

@M. I. Chaikovska

SUMMARY. Malnutrition in patients with chronic kidney disease (CKD) is associated with an increased risk of morbidity and mortality. This study shows the association of markers of nutritional status, namely, the thickness of 
Огляди літератури, оригінальні дослідження, погляд на проблему, ювілеї

skinfold, with the marker of inflammation interleukin-6 and the phosphaturic hormone, fibroblast growth factor 23 , which increases in CKD, which is associated with an increase in cardiovascular mortality.

The aim - to study the peculiarities of nutritional status of patients with CKD and to investigate the relations of FGF-23 and IL-6 with markers of nutritional status in CKD.

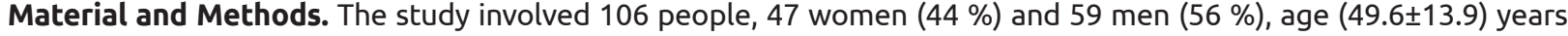
with CKD. We determined the level of albumin, IL-6, BMI, and the thickness of subscapular, triceps and abdominal skinfolds. The C-terminal fragment of FRF-23 was determined using a set of reagents for the immuno-enzyme analysis "Biomedica" and the STAT FAK 303 Plus machine.

Results and Discussion. The serum albumin level progressively decreased, reaching the minimum values at the terminal stage of renal failure $(p<0.001)$. Among patients with CKD stage $V$ malnutrition was observed in $31 \%$ of patients, of whom $10 \%$ had moderate malnutrition and $5 \%$ had severe malnutrition. The skinfold thickness was reduced in parallel with the decline of GFR, gaining statistical significance at CKD stage III $(p<0.01)$ and reaching the lowest values at CKD stage $V$. A saignificant negative relation between the skinfold thickness and FGF-23 concentration was found ( $r=-0.23$; $p<0.05$ ). A saignificant negative relation was found between the skinfold thickness and the concentration of IL-6 ( $r=-0.23$; $p<0.05)$.

Conclusions. The skinfold thickness decreases with a decline in GFR and has an inverse relation with the level of IL-6, which indicates the nutritional properties of subcutaneous fat depots and the absence of proinflammatory effects of subcutaneous fat in patients with CKD.

KEY WORDS: chronic kidney disease; nutritional status; protein-energy wasting; chronic inflammation; fibroblast growth factor 23; interleukin 6. 